\title{
Konstruksi Nilai Nasionalisme dalam Bait Sya'ir Tanpo Waton (Analisis Semiotik Model Ferdinand De Saussure)
}

\author{
M. Sabron Sukmanul Hakim \\ UIN Sunan Kalijaga, Yogyakarta \\ e-mail: Sabronsukma@gmail.com
}

\begin{abstract}
Abstrak
Setiap lagu memiliki pesan tersendiri, baik pesan duniawi maupun ukhrawi. Penelitian ini bertujuan untuk mengetahui bagaimana konstruksi nilai nasionalisme dalam bait "syi'ir tanpo waton". Analisis Semiotik yang digunakan dalam penelitian ini adalah semiotik milik Ferdinand De Saussure yang berfokus pada bagaimana suatu tanda dilihat dari sisi linguistic atau bahasanya. Hasil dari penelitian ini menunjukkan bahwa bagaimana suatu sya'ir mengkonstruksikan nilai nasionalisme, dalam hal ini adalah syi 'ir tanpo waton karangan KH Moh Nizam As Shofa. Di dalam sya'irnya terdapat nilai nasionalisme yang mendalam diantaranya; dibutuhkan hati yang bersih dan fikiran yang jernih untuk membentuk sifat nasionalisme yang murni, mengedepankan jujur dan amanah, memahami secara menyeluruh pengertian nasionalisme bukan setengah-setengah, saling tolong menolong dalam bekerja, istiqomah serta senantiasa menjalankan perintah Allah SWT dan tuntunan Rasulullah SAW.
\end{abstract}

Kata Kunci: Musik, Analisis Semiotik Ferdinand De Saussure, KH Moh Nizam As Shofa, Syi 'ir tanpo waton, Konstruksi, nasionalisme.

\begin{abstract}
Each song has its own message, both worldly and ukhrawi's message. This study aims to find out how the construction of the values of nationalism in the verse "syi'ir tanpo waton". Semiotic analysis used in this research is Ferdinand De Saussure's semiotic which focuses on how a sign is seen from the linguistic or language side. The results of this study indicate that how a poem constructs the value of nationalism, in this case is shi'ir tanpo waton by KH Moh Nizam As Shofa. In his poetry there is a deep nationalism value including; it takes a clean heart and clear mind to form a pure nature of nationalism, promoting honesty and trustworthiness, understanding comprehensively nationalism not half measures, helping each other in working, istiqomah and always carrying out the commands of Allah SWT and the guidance of Rasulullah SAW.
\end{abstract}

Keywords: Music, Ferdinand De Saussure Semiotic Analysis, KH Moh Nizam As Shofa, Syi'ir tanpo waton, Construction, nationalism. 


\section{PENDAHULUAN}

Berkaitan tentang musik, semua orang pasti mengetahui apa itu musik beserta alirannya. Sejak zaman dahulu musik sudah dikenal dan digunakan sebagai hiburan, upacara adat, pementasan, pengexpresian diri, bentuk kreatifitas, pendidikan, sarana komunikasi, sosial, dakwah, sarana tari, bahkan digunakan sebagai sarana terapi atau meditasi, dari anak-anak sampai orang tua menyukai musik sesuai kebutuhan dan tingkatan mereka masing-masing. Musik yang dimainkanpun sesuai pesan yang ada dalam lagu. Setiap lagu memiliki pesan tersendiri, baik menyangkut kehidupan dunia maupun akhirat. Musik memiliki cakupan yang luas, tidak hanya sebatas irama dan lantunan nada, namun lebih dari itu musik menjadi sarana seseorang untuk mengungkapkan apa yang dirasakan dan difikirkannya. Dalam hal ini penulis akan menganalisis konstruksi nilai-nilai nasionalisme dalam teks syi'ir tanpo waton karangan KH Moh Nizam As Shofa, dengan menggunakan analisis semiotik Ferdinand de Saussure.

Menurut KBBI, musik adalah suatu cabang ilmu atau cabang seni yang digunakan untuk penyusunan nada dan suara dalam suatu urutan tertentu, kombinasi tertentu serta menimbulkan hubungan temporal untuk menghasilkan sebuah komposisi dan susunan yang bersatu dan saling bersinambung. Sedangkan menurut Aristoteles, musik merupakan suatu bentuk curahan hati dan kemampuan tenaga yang mampu memberikan gambaran dan diperoleh dari gerakan rasa dalam sebuah rentetan nada dan melodi yang berirama. Menurut Ajie Esa Poetra adalah sebuah gabungan bunyi yang sifatnya saling teratur, tidak hanya bersifat normatif, namun juga diakui menjadi sebuah bentuk yang selaras berdasar perhitungan dari para ilmuwan yang concern di bidang fisika.

Musik juga berperan dalam evolusi manusia, dibalik perilaku dan tindakan manusia terdetak fikiran dan perkembangan diri akibat bias daripada musik. Pemakaian bahasa pada sebuah karya seni bertolak belakang dengan penggunaan bahasa sehari-hari atau dalam kegiatan lain. Musik memiliki pengaruh yang erat dengan setting sosial kemasyarakatan tempat dia berada, sehingga menyimpan makna yang tersembunyi dan berbeda. Musik dapat juga digunakan sebagai media dalam menyampaikan suatu pesan kepada masyarakat. Pesan yang disampaikan 
tersebut beraneka ragam, mulai dari pesan yang hanya bertujuan mengeksplor akan suatu hal sampai mengajak melakukan sesuatu. Salah satu contoh pesan yang biasa disampaikan adalah pentingnya rasa nasionalisme terhadap bangsa sendiri. Nasionalisme adalah satu paham yang berpendapat bahwa kesetiaan tertinggi individu harus diserahkan kepada kebangsaan (Kohn, 1984:11).

Perasaan yang mendalam akan suatu ikatan dengan tanah tumpah darahnya, dengan tradisi-tradisi masyarakat setempat dan penguasa-penguasa resmi di daerahnya selalu hadir di sepanjang sejarah dengan kekuatan yang berbeda-beda. Nasionalisme dalam arti kata modern menjadi suatu hal yang diakui secara umum. Dan nasionalisme ini makin lama makin kuat peranannya dalam membentuk berbagai macam sendi kehidupan, menciptakan dan mempertahankan kedaulatan sebuah negara, negaranya sendiri, dan bahwa negara itu harus meliputi seluruh bangsa. Ikatan nasionalisme tumbuh ditengah masyarakat saat pola pikirnya mulai merosot. Ikatan ini terjadi saat manusia mulai hidup bersama dalam suatu wilayah tertentu dan tidak beranjak dari situ. Saat itu, naluri mempertahankan diri sangat berperan dan mendongkrak mereka untuk mempertahankan negerinya, tempatnya hidup dan menggantungkan diri. Dari sinilah cikal bakal tumbuhnya ikatan, yang notabene lemah dan bermutu rendah. Salah satu lagu dalam bentuk sya'ir yang menggambarkan Nasionalisme adalah syi'ir tanto waton karangan KH Moh Nizam As Shofa. Dalam syi'ir tersebut ada beberapa kutipan yang menggambarkan makna nasionalisme, bagaimana memaknai dan menggunakan jabatan dengan baik. Berikut kutipannya dalam bahasa Indonesia:

banyak yang hapal Qur'an dan Haditsnya

senang mengkafirkan kepada orang lain

kafirnya sendiri tak dihiraukan

jika masih kotor hati dan akalnya $2 \mathrm{x}$

gampang terbujuk nafsu angkara

dalam hiasan gemerlapnya dunia

iri dan dengki kekayaan tetangga

maka hatinya gelap dan nista $2 \mathrm{x}$

ayo saudara jangan melupakan

wajibnya mengkaji lengkap dengan aturannya 
untuk mempertebal iman tauhidnya

bagusnya bekal mulia matinya $2 \mathrm{x}$

terhadap teman, saudara dan tetangga

yang rukun jangan bertengkar

itu sunnahnya Rosul yang mulia

Nabi Muhammad tauladan kita 2x

ayo jalani semuanya

Allah yang akan mengangkat derajatnya

Walaupun rendah tampilan dhohirnya

namun mulia maqam derajatnya disisi Allah

Dalam cuplikan sya'ir tersebut tergambar bahwa banyak yang tertipu dengan gemerlapnya dunia, salah memaknai nasionalisme dan seringkali berbuat curang bahkan menyakiti sesama atas nama agama dan nasionalisme. Ini karena pemahaman yang kurang mendalam serta hati yang ternoda, sehingga akalnya tidak mampu menimbang mana yang baik dan mana yang buruk, hatinya sulit membedakan mana yang hak dan mana yang bathil. Semua kembali kepada pedoman Islam yang mulia, Al-Qur'an dan Hadits serta akhlakul karimah sebagaimana yang telah dicontohkan nabi. Berdasarkan latar belakang tersebut penelitian ini dirumuskan dalam pokok pembahasan bagaimana bentuk konstruksi nilai nasionalisme dalam lirik Syi'ir tanpo waton. Tujuan penelitian ini adalah untuk mengetahui nilai-nilai Nasionalisme yang terkandung dalam syi'ir tanpo waton.

\section{Musik Sebagai Komunikasi}

Musik merupakan sebuah seni yang melekat melalui media berupa suara. Musik dapat juga bermakna nada atau suara yang dirangkai dan terangkai sedemikian rupa sehingga memiliki irama, lagu dan keharmonisan. Musik kerap kali menjadi pijakan lembah untuk menuangkan ungkapan seni, kreativitas, ekspresi. Setiap orang dalam menerima dan menilai musik memiliki cara dan kesan yang berbeda. Perbedaan itu dapat berdasarkan lokasi, budaya dan selera masing-masing individu. Musik mencerminkan rona dan suasana kebudayaan masyarakat pendukungnya. Musik itu sendiri memiliki bentuk yang khas, baik 
dari sudut struktural maupun jenisnya dalam kebudayaan. Teori tentang musik adalah cabang ilmu yang menjelaskan tentang unsur-unsur musik, seperti nada, suara, intonasi, ritme, dan lain sebagainya.

Teori musik juga meliputi pengembangan dan penerapan metode guna menganalisis maupun menggubah musik, serta rangkaian antara notasi musik dan pembawaan musik. Komunikasi adalah sebuah ilmu yang sangat erat kaitannya dengan manusia dan interaksi didalamnya. Komunikasi adalah hal yang sangat sering kita dengarkan dan selalu kita terapkan dalam kehidupan sehari-hari. Setiap orang selalu melakukan sebuah komunikasi dan tidak dapat terlepas dari praktik itu, dimulai dari yang paling mendasar yaitu komunikasi dengan diri sendiri, kemudian bertemu orang lain dan berkomunikasi ke lingkup yang lebih luas. Di dalam situasi dan konteks yang begitu luas, komunikasi memainkan peran utama (basic) dan pokok (fundamental). Begitu mendasarnya sehingga dengan serta merta komunikasi dipandang sebagai suatu kebenaran dan begitu saja diterima oleh akal sehat. Akan tetapi, ketika seseorang mempertimbangkan berbagai problematika sebagai akibat dari komunikasi yang buruk dan tidak jelas, kompleksitas dan tantangan yang berkaitan dengan proses komunikasi menjadi jelas bahwa sikap yang seperti itu kurang tepat. Definisi dan teori itu banyak dan terkadang menuai pertentangan.

Komunikasi memiliki sejarah yang kaya dan panjang, yang dapat ditelusuri kembali dalam goresan tinta bangsa babilonia dan mesir sebelum abad ke-5 SM. Kontribusi awal untuk studi komunikasi berasal dari para ahli retorika. Mereka memandang komunikasi sebagai seni praktis dari persuasi. Aristoteles dan plato, adalah dua orang yang pertama kali melakukan studi komunikasi, menunjukan retorika dan praktik public speaking bukan hanya sebagai seni namun juga sebagai bidang pelajaran yang masuk akal. Selama awal abad ke-20, minat terhadap komunikasi berlanjut dalam bidang retorika dan pidato, ditemukannya radio dan televisi telah menyebabkan penerapan konsep jurnalisme menjadi lebih luas dan pengembangan teori-teori mencakup keseluruhan proses jurnalisme.

Pada awal abad ke-21, disiplin komunikasi dan studi mengenai fenomena komunikasi menjadi perhatian utama dalam urusan kemanusiaan. Yang menjadi 
pokok masalahnya, sebagaian sudah kuno dan sebagian lagi muncul, adalah disiplin komunikasi itu sendiri dan interdisiplin dari beragam ahli dan berbagai bidang. Komunikasi merupakan hal yang relevan untuk urusan pribadi dan urusan profesional. Peran teknologi baru dan teknologi lama terus menjadi fokus perhatian dalam periode ini. Fokus kajian bidang komunikasi adalah keterampilan yang paling praktis sekaligus hal-hal yang paling menjadasar dari proses kehidupan.

\section{Nasionalisme}

Nasionalisme adalah perasaan satu keturunan, senasib, sejiwa dengan bangsa dan tanah airnya. Nasionalisme yang dapat menimbulkan perasaan cinta kepada tanah air disebut patriotisme. Nasionalisme dibedakan menjadi dua yaitu : 1. Nasionalisme dalam arti luas yaitu perasaan cinti / bangga terhadap tanah air dan bangsanya dengan tidak memandang bangsa lain lebih rendah derajatnya.

2. Nasionalisme dalam arti sempit yaitu perasaan cinta/bangga terhadap tanah air dan bangsanya secara berlebihan dengan memandang bangsa lain lebih rendah derajatnya. Nasionalisme Indonesia adalah nasionalisme yang berdasarkan Pancasila yang selalu menempatkan kepentingan bangsa dan negar di atas kepentingan pribadi dan golongan.

Nasionalisme Indonesia adalah perasaan bangga/cinta terhadap bangsa dan tanah airnya dengan tidak memandang bangsa lain lebih rendah derajatnya. Dalam membina nasionalisme harus dihindarkan paham kesukuan chauvinisme, ekstrimisme, kedaulatan yang sempit. Pembinaan nasionalisme juga perlu diperhatikan paham kebangsaan yan gmengandung penegrtian persatuan dan kesatuan Indonesia, artinya persatuan bangsa yang mendiami wilayah Indonesia.

Nasionalisme dan patriotisme sangat penting bagi kelestarian kehidupan bangsa Indonesia. Hal ini mengingat kondisi : 1. Masyarakat Indonesia adalah masyarakat yang majemuk atau keanekaragaman dalam suku, ras, golongan, agama, budaya dan wilayah. 2. Alam Indonesia, dimana kepualauan nusantara terletak pada posisi silang yang dapat mengandung kerawanan bahaya dari negara lain. 3. Adanya bahaya disintegrasi (perpecahan bangsa) dan gerakan separatisme 
(gerakan untuk memisahkan diri dari suatu bangsa), apabila pemerintah tidak bersikap bijaksana. Semangat kebangsaan dapat diwujudkan dengan adanya sikap patriotisme dan nasionalisme dalam kehidupan seharihari. Warga negara yang memiliki semangat kebangsaan yang tinggi akan memiliki nasionalisme dan patriotisme yang tinggi pula.

\section{Perwujudan Nasionalisme dalam Kehidupan}

Perwujudan nasionalisme dan patriotisme bagi bangsa Indonesia dapat dilihat dari perjalanan sejarah bangsa Indonesia antara lain : 1. Sebelum Masa Kebangkitan Nasional Perjuangan bangsa Indonesia untuk membela tanah air atau jiwa patriotisme sebelum kebangkitan nasional, masih bersifat kedaerahan, tergantung pada pemimpin, belum terorganisir dan tujuan perjuangan belum jelas. 2. Masa Kebangkitan Nasional Perjuangan bangsa Indoensia tidak lagi bersifat kedaerahan, tapi bersifat nasional. Perjuangan dilakukan dengan cara organisasi modern, dimana sejak berdirinya Budi Utomo merupakan titik awal kesadaran nasionalisme. Masa ini disebut angkatan perintis, sebab disamping merintis kesadaran nasional juga merintis berdirinya organisasi. 3. Masa Sumpah Pemuda Sumpah pemuda merupakan tonggak sejarah bagi perjuangan bangsa Indonesia. Yang jelas dan tegas dalam menuntut kemerdekaan bagi bngsa Indonesia. Sumpah pemuda mengandung nilai yang sangat tinggi yaitu nilai persatuan dan kesatuan yan gmerupakan modal perjuangan untuk mencapai kemerdekaan. Masa ini d sebut angkatan penegas, sebab angkatan inilah yang menegaskan pentingnya persatuan dan kesatuan bangsa dalam berjuang mencapai kemerdekaan. 4. Masa proklamsi kemerdekaan Proklamasi kemerdekaan merupakan titik kulminasi (puncak) perjuangan bangsa Indoensia, juga merupakan wujud perjuangan yang berdasarkan persatuan Indonesia.

Oleh karena itu, semangat kebangsaan, semangat persatuan dan kesatuan bangsa yang mengantarkan Indoensia mencapai tonggak sejarah yang paling fundamental harus kita jaga dan kita pertahankan. Proklamasi kemerdekaan merupakan jembatan emas yan gakan mengantarkan bangsa Indoensia menuju cita-cita nasional yaitu masyarakat yang merdeka, berdaulat, adil dan makmur. 
Perwujudan semangat kebangsaan dan patriotisme yang berupa sika prela berkorban untuk kepentingan tanah air, bangsa dan negara sebagai tempat hidup dan kehidupan dengan segala apa yan gdimiliki, akan memperkuat pertahanan dan keamanan nasional, proklamasi kemerdekan yang dicita-citakan telah terwujud, berkas perjuangan dan pengorbanan para pahlawan. Maka kita harus dapat mengisi kemerdekaan ini dengan membangun berbagai macam bidang agar dapat mempercepat tercapainya tujuan bangsa Indonesia. Guna mencapai tujuan bangsa diharapkan peran serta seluruh bangsa dalam membangun negara, karena kita sebagian besar tidak mengalami peristiwa perjuangan kemerdekaan, maka perlunya dipahami, dimenegrti akan arti perjuangan para pejuang, niscaya tujuan negara yang diidam-idamkan akan segera terwujud.

Penelitian ini menggunakan jenis penelitian kualitatif. Menurut Moleong (2007: 4), mengemukakan bahwa metodologi kualitatif adalah metode penelitian yang berlandaskan pada kata-kata yang tertulis maupun secara lisan dari tindakan bisa yang dilihat. Peneliti menggunakan metode kualitatif dengan pendekatan deskriptif dikarenakan peneliti ingin menganalisa nilai nasionalisme yang terkandung dalam beberapa bait lagu syi'ir tanpo waton. Pola penelitian yang digunakan dalam penelitian ini adalah deskriptif, yaitu pemaparan atas data atau uraian dan konstruksi nilai nasionalisme dalam bait syi'ir tanpo waton.

\section{Bait III}

\begin{tabular}{|c|c|}
\hline Penanda & Petanda \\
\hline $\begin{array}{l}\text { Akeh kang apal Qur'an Hadiste } \\
\text { Seneng Ngafirkeh marang liyane } \\
\text { Kafire dewe Ga' di gatekke } \\
\text { Yen isih kotor ati akale } 2 \mathrm{x} \\
\text { banyak yang hapal Qur'an dan } \\
\text { Haditsnya } \\
\text { senang mengkafirkan kepada orang } \\
\text { lain } \\
\text { kafirnya sendiri tak dihiraukan }\end{array}$ & $\begin{array}{l}\text { Dalam bait ini pengarang ingin } \\
\text { mengungkapkan fakta yang sering } \\
\text { terjadi saat ini bahwa banyak orang } \\
\text { yang menghafal Al-Qur'an dan Hadits, } \\
\text { namun tidak faham akan makna yang } \\
\text { terkandung di dalamnya. Banyak yang } \\
\text { tidak menginstropeksi diri, terlihat } \\
\text { dalam lirik banyak yang senang } \\
\text { mengkafirkan orang lain, namun }\end{array}$ \\
\hline
\end{tabular}




\begin{tabular}{|l|l|}
\hline jika masih kotor hati dan akalnya 2x & $\begin{array}{l}\text { perbuatan kafirnya sendiri tidak } \\
\text { dihiraukan, ditambah factor yang aling } \\
\text { utama adalah kotornya hati dan akal } \\
\text { fikiran. }\end{array}$ \\
\hline
\end{tabular}

Daalam bait ini tersirat makna singgungan yang dalam terhadap orangorang yang tau agama, hafal dalil-dalil Al-Qur'an dan Haditsnya, namun tidak mengamalkan isinya. Mereka menjadi buta sendiri akan ilmu yang dimilikinya. Mereka menjustifikasi seseorang dengan kepribadian yang buruk, padahal dia sendiri yang berbuat buruk. Menyalahkan dan menjatuhkan orang lain tanpa alasan yang jelas, hanya untuk kepentingan pribadinya. Hal tersebut merupakan fakta yang banyak terjadi saat ini, khususnya di Indonesia, banyak yang menganggap dirinya paling nasionalis namun menimbulkan banyak perpecahan, menganggap orang lain anti NKRI, namun dia sendiri yang merusaknya. Salah satu faktor yang menyebabkan semua ini terjadi adalah karena masih kotornya hati dan akal fikiran seseorang, seperti yang tertulis dalam bait sya'ir di atas. Pesan yang terdapat dalam bait tersebut adalah, untuk menciptakan rasa nasionalisasi yang sesungguhnya, dibutuhkan hati yang bersih dan fikiran yang jernih.

Kita seringkali menutup-nutupi kebenaran atas dasar kepentingan pribadi dan materi lainnya, menampakkan keburukan seolah-olah itu dibolehkan dengan mengutip ayat-ayat yang ditafsirkan sesuka hatinya. Menggunakan dalil untuk membungkus keburukan yang kita lakukan, seakan hukum mengikuti nafsunya bukan dia yang mengikuti hukum. Jika demikian halnya, dimana fungsi Al-Qur'an sebagai pedoman hidup ?, dimana posisi kita sebagai seorang hamba yang senantiasa mengikuti aturan-Nya?, Allah SWT telah menegaskan dalam AlQur'an Surat A1-Baqarah ayat 42:

Wa laa talbisul haqqo bil baathili wa taktumul haqqo wa antum ta'lamuun. "Dan janganlah kalian membungkus kebenaran dengan keburukan, dan menutup kebenaran padahal kalian mengetahui. “

Dalam ayat tersebut, Allah bukan hanya melarang tegas namun juga menyindir atau menegur orang yang sudah mempelajari dan mengetahui hukum 
agama, namun tidak menyuarakannya, malah menutupi dan membenarkan yang buruk. Sebuah kata mutiara berbunyi "katakanlah kebenaran walaupun itu pahit". Seiring dekatnya sebuah hubungan, terkadang kita malu untuk menegur saudara, sahabat, dan orang-orang terdekat kita, merasa takut dibenci, dikucilkan dan sebagainya. Padahal dengan membiarkannya terlena akan semakin berdampak baik .bagi pelaku keburukan tersebut. Kendati demikian, seyogyanya kita menasehati, menegur secara halus, sebagai wujud kasih sayang kita terhadap sesama dan bentuk penghambaan kita terhadap Yang Maha Kuasa.

Dapat kita perhatikan, dalam ayat tersebut mengandung makna bahwa segala sesuatu yang namanya kebenaran tetaplah sebuah kebenaran, tidak bisa dihiasi dengan kebathilan, sedangkan kebathilan tetaplah sebuah kebathilan walaupun dibungkus dengan kebenaran. Artinya bahwa suatu kebenaran pasti akan selalu terungkap, begitupula dengan keburukan, sekuat apapun ditimbun, namun pada akhirnya akan tercium juga. Bertopeng indah namun dibaliknya rusak, dibungkus rapi namun isinya tidak karuan. Terlebih di zaman globalisasi saat ini, zaman teknologi serba canggih, dimana akses informasi begitu cepat, beragam media saling berpacu merebut bintang, mengarahkan pembaca kepada apa yang diinginkan media itu ataupun orang tertentu, dengan berbagai cara menghias kata terlepas dari baik tidaknya cara atau sesuai tidaknya dengan yang nyata, karena media sifatnya sangat bebas dan tidak terbatas bagi siapapun yang ingin berkecimpung di dalamnya, tanpa memandang strata sosial maupun pendidikan.

Tabel. 1 Bait IV

\begin{tabular}{|l|l|}
\hline \multicolumn{1}{|c|}{ Penanda } & \multicolumn{1}{|c|}{ Petanda } \\
\hline Gampang kabujuk Nafsu angkoro & Dalam bait ke IV ini masih terkait \\
Ing pepaese Gebyare ndunyo & dengan bait ke III bahwa yang \\
Iri lan meri sugi e tonggo & menyebabkan hati menjadi buta adalah \\
Mulo atine peteng lan Nisto 2X & karena gemerlap dunia. Banyak yang \\
& tersesat akan tujuan utamanya untuk \\
gampang terbujuk nafsu angkara & sama-sama membangun suatu bangsa \\
dalam hiasan gemerlapnya dunia & dan agama, tergambar dalam bait \\
\hline
\end{tabular}




\begin{tabular}{|l|l|}
\hline iri dan dengki kekayaan tetangga & tersebut disebutkan bahwa banyak yang \\
maka hatinya gelap dan nista $2 \mathrm{x}$ & iri dan dengki dengan kekayaan \\
tetannga, dimana iri dan dengki \\
merupakan penyakit hati, yang \\
membuat hati akan menjadi gelap dan \\
penuh nista/ kebohongan.
\end{tabular}

Bait tersebut masih berkaitan denga hati, di sini disebutkan bahwa penyebab dari gelapnya hati adalah terpesona dengan keindahan dunia, gemerlap perhiasan dan materi. Semua itu akan membutakan hati yang awalnya cinta menjadi benci terhadap sesama, hanya karena kepentingan materi semata. Perbedaan pilihan menyebabkan permusuhan dan perpecahan. Bagaimana suatu bangsa dapat maju apabila penduduknya banyak yang bermusuhan, bagaimana nasionalisme dapat terbentuk jika di dalam tubuh bangsa itu sendiri terjadi perpecahan dan kebencian. Di bait tersebut disebutkan juga bahwa hati yang kotor akan penuh dengan kebohongan belaka dan tidak adanya rasa saling percaya terhadap sesama saudara. Kalau amanah sudah tidak dijaga maka akan mudah terjadi kehancuran.

Amanah yang seharusnya ditunaikan menjadi terlantarkan, karena saat itu iman sedang kosong. Seperti yang dijelaskan dalam sebuah hadits "Tidak ada iman bagi mereka yang tidak memiliki amanah." Salah satu contohnya yang paling nyata kita lihat kemarin adalah bagaimana problematika pasca pemilu presiden, banyak yang saling mencela, menjadikan agama sebagai tameng dalam berkampanye, menjual ayat-ayat Al-Qur'an untuk memenangkan calon yang dipilihnya dan menjatuhkan lawan politiknya. Mereka memiliki tujuan yang baik namun dalam mencapainya menggunakan cara yang buruk. Agama hanya dijadikan pemuas nafsu, mengisi kebutuhan duniawi yang seakan-akan sekedar alat untuk meraih kesenangan duniawi, mereguk harta, mengharap tahta dan mengejar jabatan. Boleh mengikuti zaman namun iman jangan sampai tergadaikan. 
Tabel 2. Bait V

\begin{tabular}{|l|lr|}
\hline \multicolumn{1}{|c|}{ Penanda } & \multicolumn{2}{|c|}{ Petanda } \\
\hline Ayo sedulur Jo nglale ake & Dalam bait tersebut pengarang \\
Wajibe ngaji sak pranatane & mengajak kita semua untuk belajar \\
Nggo ngandelake iman Tauhide & dengan tekun dan sampai tuntas, tidak \\
Baguse sangu mulyo matine & setengah-setengah, karena belajar yang \\
ayo saudara jangan melupakan & setengah-setengah juga akan \\
wajibnya mengkaji lengkap dengan & menghasilkan pemahaman yang \\
aturannya & setengah-setengah. Inilah yang \\
untuk mempertebal iman tauhidnya & menyebabkan goyahnya iman, sehingga \\
bagusnya bekal mulia matinya 2x & mudah terbujuk rayu syaitan. Karena \\
& sebaik-baik bekal akhirat adalah \\
& keimanan dan ketakwaan. \\
\hline
\end{tabular}

Dalam bait tersebut tampak bahwa pengarang mengajak kita semua untuk belajar yang tekun dan secara tuntas, serta belajar pada ahlinya. Banyak yang sesat pemahaman karena pengetahuan yang setengah-setengah, banyak yang terjerumus ke lembah kenistaan karena terbujuk rayu syaitan. Ilmu yang tidak tuntas dipelajari akan membuat gagal faham dan rusaknya persepsi terhadap sesuatu. Iman yang kuat sangat dibutuhkan untuk kokohnya sebuah persatuan. Sebagai tameng dari gangguan yang muncul, baik dari dalam diri kita maupun luar. Iman yang kokoh menandakan spiritual yang tinggi. Dengan spiritual yang tinggi ini akan melahirkan sifat kejujuran dan amanah. Kalau sifat jujur dan amanah sudah tertanam dalam diri sesorang, maka akan terjalin rasa kasih sayang dan kerjasama yang baik.

Tabel 3. Bait XI

\begin{tabular}{|l|l|}
\hline \multicolumn{1}{|c|}{ Penanda } & \multicolumn{2}{|c|}{ Petanda } \\
\hline $\begin{array}{l}\text { Kelawan konco dulur lan } \\
\text { tonggo } \\
\text { Kang podo rukun ojo daksio }\end{array}$ & $\begin{array}{l}\text { Dalam bait tersebut, pengarang mengajak kita } \\
\text { teman hidup rukun terhadap sesama saudara, } \\
\text { tetangga. Karena hidup rukun }\end{array}$ \\
\hline
\end{tabular}




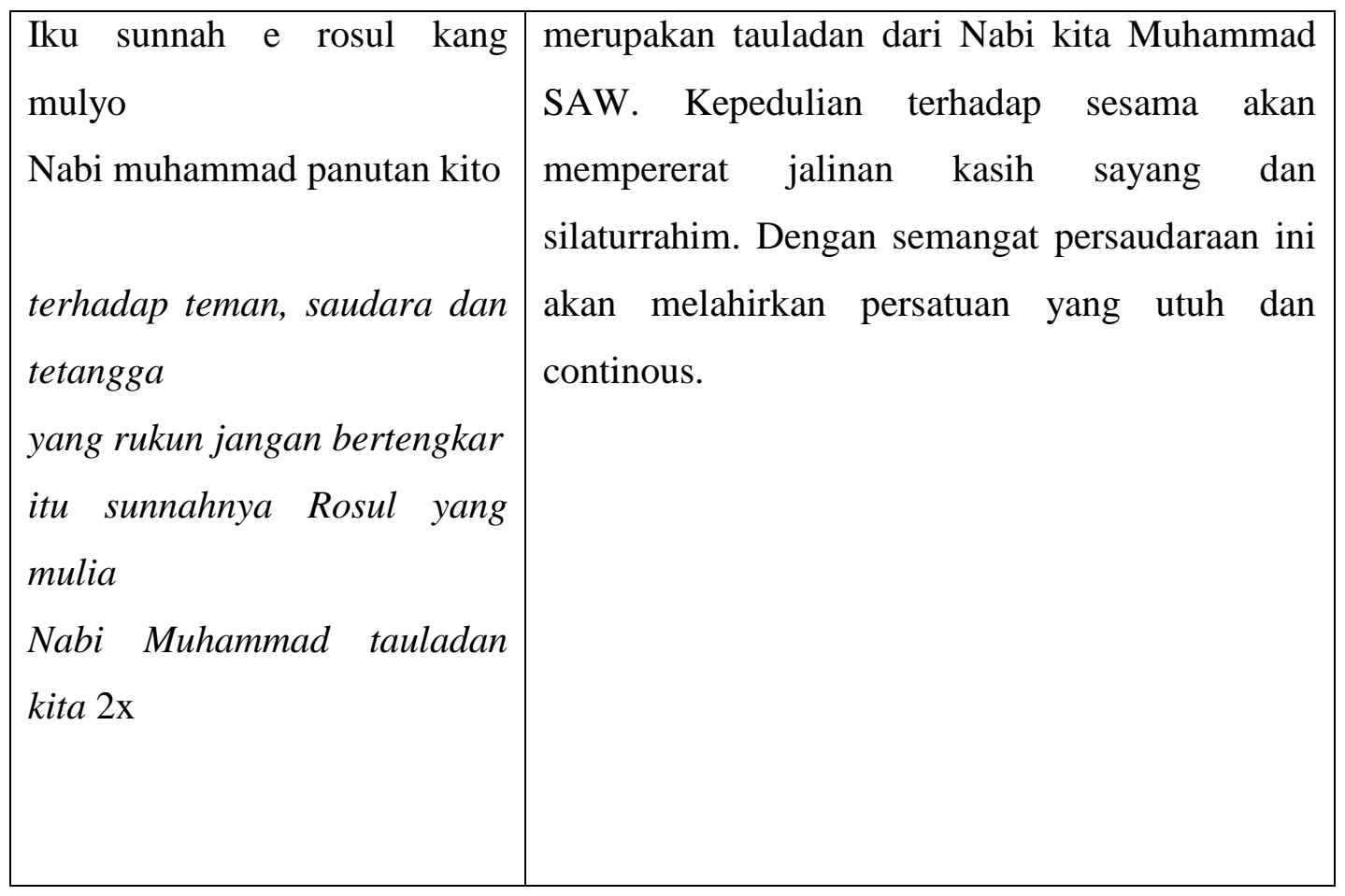

Dalam bait ke XI tersebut, ada nilai dan semangat persaudaraan yang terpancarkan. Cahaya dari persaudaraan ini akan menuntun kita kepada persatuan yang utuh dan continuous. Persatuan yang akan tetap terjaga dalam suatu bangsa. Karena Rasulullah SAW telah berjanji bahwa barang siapa yang mengikuti Allah dan Rasul-Nya tidak akan tersesat di dunia maupun di akhhirat. Dan salah satu tauladan Rasulullah SAW adalah menjaga kerukunan dan saling tolong menolong sesama saudara, teman dan tetangga kita, sebagaimana Allah SWT berfirman yang artinya:

Dan tolong-menolonglah kamu dalam (mengerjakan) kebajikan dan takwa, dan jangan tolong-menolong dalam berbuat dosa dan pelanggaran. Dan bertakwalah kamu kepada Allah, sesungguhnya Allah amat berat siksa-Nya [alMâidah/5:2].

Dalam ayat tersebut tergambar jelas seruan Allah SWT untuk saling tolong menolong antar sesama saudara, tentunya dalam hal kebaikan dan takwa, saling memperingati dan mengajak untuk berbuat kebaikan. Alangkah indahnya hidup ini jika diisi dengan sesuatu yang baik. Terutama dalam hal menjaga persatuan, tauladan tersebut sangat perlu untuk dicontohi. Ada dua bentuk tolong menolong 
yang digambarkan dalam ayat tersebut, yaitu tolong menolong dalam berbuat kebaikan dan tolong menolong dalam perbuatan jahat. Tolong menolong dalam berbuat kebaikan didasari oleh rasa taka kepada Allah SWT, sedangkan tolong menolong dalam kejahatan, dilandasi hawa nafsu dan bisikan syaitan. Sebagai makhluk yang dikaruniai sebuah akal, tentunya kita akan lebih memilih untuk menolong dalam kebaikan. Bagaimana cara mengetahui bahwa hal tersebut baik?, tentunya dengan ilmu yang telah kita pelajari.

Bait XII

\begin{tabular}{|c|c|}
\hline Penanda & Petanda \\
\hline $\begin{array}{c}\text { Ayo nglakoni sekabeane } \\
\text { Alloh kang bakal ngangkat } \\
\text { drajate } \\
\text { Senajan ashor toto dhohire } \\
\text { Ananging mulyo makom } \\
\text { drajate } \\
\text { ayo jalani semuanya } \\
\text { Allah yang akan mengangkat } \\
\text { derajatnya } \\
\text { Walaupun rendah tampilan } \\
\text { dhohirnya } \\
\text { namun mulia maqam } \\
\text { derajatnya di sisi Allah }\end{array}$ & $\begin{array}{l}\text { Daalam bait tersebut, pengarang berpesan bahwa } \\
\text { bagaimanapun kedudukan kita di dunia, yang } \\
\text { menentukan adalah tingkat derajat kkita di sisi } \\
\text { Allah SWT. Walaupun kita terlihat rendah di } \\
\text { dunia, namun bisa jadi kita menempati } \\
\text { kedudukan mulia di sisi Allah SWT. Karena } \\
\text { yang terpenting dalam hidup ini adalah } \\
\text { bagaimana meningkatkan ketakwaan kita kepada } \\
\text { Allah SWT. Walau pun kita berkedudukan } \\
\text { rendah di dunia, khususnya dalam Negara } \\
\text { Indonesia. Kita harus tetap bersama ikut } \\
\text { membangun persatuan bangsa ini. }\end{array}$ \\
\hline
\end{tabular}

Di bait ke XII ini, digambarkan kedudukan yang mulia bagi yang istiqamah menjalankan kebaikan. Pengarang berpesan kepada kita untuk senantiasa menjaga persaudaraan dan persatuan bagaimanapun kedudukan atau jabatan, tinggi ataupun rendahnya dalam suatu bangsa. Karena perintah saling tolong menolong dan menjaga persatuan adalah untuk semua ummat manusia, bukan kalangan tertentu. Semakin besar ketakwaan kita, akan semakin mulia kita di sisi Allah SWT. Sifat 
nasionalisme harus tetap tertanam dalam diri kita, saling bahu membahu dalam kebaikan dan persatuan, sehingga persatuan akan dapat terealisasikan.

\section{SIMPULAN}

Di samping sebagai seni hiburan, musik juga digunakan untuk menyampaikan pesan kepada khalayak, dalam bentuk nasihat, pendidikan, dakwah, dan sebagainya. Salah satunya yang dibahas di sini adalah bagaimana suatu sya'ir mengkonstruksikan nilai nasionalisme, dalam hal ini adalah syi'ir tanpo waton karangan $\mathrm{KH}$ Moh Nizam As Shofa. Di dalam sya'irnya terdapat nilai nasionalisme yang dalam diantaranya; dibutuhkan hati yang bersih dan fikiran yang jernih untuk membentuk sifat nasionalisme yang murni, mengedepankan jujur dan amanah, memahami secara menyeluruh pengertian nasionalisme bukan setengah-setengah, saling tolong menolong dalam bekerja, istiqomah serta senantiasa menjalankan perintah Allah SWT dan tuntunan Rasulullah SAW.

\section{DAFTAR PUSTAKA}

Ardianto, Elvinaro, dan Lukiati komala Erdinaya, 2004. Komunikasi massa : suatu pengantar, Bandung : Remaja Rosdakarya.

Bulaeng Andi. 2014. Metode Penelitian komunikasi kontemporer, Yogyakarta : Andi.

Hartanto, Agus, 2010, Imaji Musik Teks, Yogyakarta : Jalasutra. https://lirik.kapanlagi.com/artis/sholawat/syiir-tanpo-waton/.

Sakrie, Denny. 2015. 100 Tahun Musik Indonesia, Jakarta : Gagas Media.

Sobur, Alex. 2009. Semiotika Komunikasi, Bandung: PT Remaja Rosdakarya.

Wacana Media.

Wibowo, Seto Wahyu Indiwan, 2013, Semiotika Komunikasi. Jakarta : Mitra 